\title{
Trends in A8 migration to the UK during the recession
}

David McCollum and Allan Findlay

ESRC Centre for Population Change, Geography, School of the Environment

University of Dundee

\begin{abstract}
A substantial proportion of contemporary migration flows to the UK are made by nationals from countries which have recently joined the EU. The nature of A8 migration during the recession is examined in this paper, mainly using data from the Worker Registration Scheme. The recession has seen a decline in new A8 migrants entering the UK labour market, but the decline has been sectorally uneven, with demand for migrant labour being most persistent in the agricultural sector, raising questions about why this part of the UK economy is so different.
\end{abstract}




\section{Introduction}

In a relatively short space of time Eastern Europe has become one of the principal source regions of migrants to the UK and citizens from these states now constitute some of the largest foreign born populations in the country. Since their accession to the European Union in May 2004 citizens from Poland, the Czech Republic, Estonia, Hungary, Latvia, Lithuania, Slovakia and Slovenia (the A8 countries) have had the right to participate in the UK labour market. Most EU member states set down constraints on the rights of A8 citizens to participate in their labour markets, but the UK, along with Ireland and Sweden, granted full access. As a result large numbers of migrants from the 'A8' countries came to the UK from 2004 onwards.

The 2004 Accession Treaty allowed 'transitional measures' to be applied to new countries joining the EU for a maximum of up to seven years. These measures have now expired (on 30 April 2011), raising the possibility that A8 migrants may now choose to move to geographically closer countries such as Germany, Austria or the Netherlands rather than the UK. The end of transitional arrangements has coincided with a period of economic recession, giving other reasons for new patterns of migration trends.

These historical and economic changes make analysis of data on A8 migration to the UK during the seven years since EU expansion particularly timely. This article seeks to deepen geographical understanding of where migrants locate in the labour market by analysing Worker Registration Scheme (WRS) data for the period May 2004 - June 2010. Earlier work reported on the distinctive geographies of immigration that emerged in the first two years after accession ${ }^{1}$. This article suggests that economic recession has produced significant changes in these migration geographies. The two central questions posed by this article are therefore:

- how has recession changed the local geographies of A8 migration to the UK?

- have these changes been related to sectoral labour market geographies?

\section{Data and methods of analysis}

This article draws primarily on data from the WRS over the period May 2004 - June 2010 (the most recent date for which WRS figures were available to the researchers at the time of analysis) and the Annual Population Survey. To estimate the impact of recession on sectoral and spatial patterns, quarterly WRS figures are compared for the second quarter of 2008 and the second quarter of 2009. The second quarter of 2008 represents the last quarter prior to the UK recession impacting on migrant registrations, while the second quarter of 2009 was when registrations hit their lowest point in the dataset available to the researchers. Differences in the volume of WRS registrations between these two periods were then used to explore the impact of the recession using a simple set of Chi-square analyses to test for the significance of reductions in WRS registrations in particular sectors and areas relative to aggregate British trends. Finally sectoral variations in the decline of WRS registrations are compared with jobs lost in the overall workforce over the same period. These have been calculated in order to discover whether there has been a differential impact of the recession on migrant and non-migrant employment. The analysis is therefore largely descriptive, since the aim of the article is primarily to provide a picture of changes in A8 immigration during the recession. 
Despite some limitations, administrative datasets such as the WRS and National Insurance Number (NINo) allocations are the most comprehensive and widely used sources of data on the numbers of A8 migrants coming to the UK. Nearly one and a half million $(1,483,240)$ NINos have been issued to nationals from the new accession states between April 2004 and March 2010 and nationals from these countries constitute 39.1 per cent of all NINos issued to overseas nationals in this period ${ }^{2}$. Figure 1 below shows the trend in how NINo allocations to A8 and other nationals has changed over time. Numbers of new A8 migrants increased steadily from the accession in May 2004 to the middle of 2005, when they levelled off for about a year. Inflows of A8 migrants peaked at the beginning of 2007 and have since declined. Up until mid-2007 temporal trends in A8 migration mirrored those of other immigrants; however since then the number of new migrants from Eastern Europe has declined, whereas inflows of immigrants from elsewhere have not.

\section{Figure $1 \quad$ National Insurance Number allocations April 2004 - March 2010}

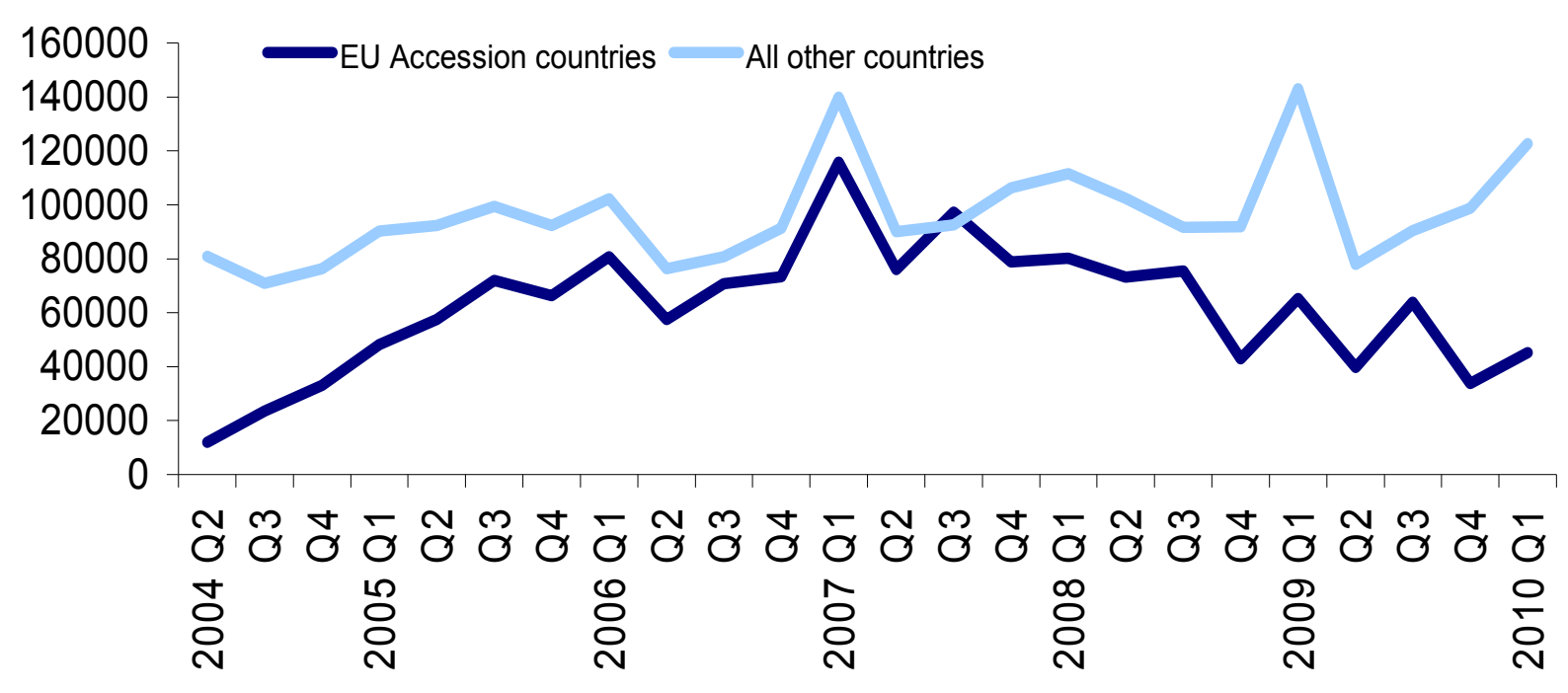

Source: Author's analysis of DWP ${ }^{2}$

A greater number of NINos have been issued to A8 migrants than WRS registrations. The higher figure from the NINo data is predominantly a reflection of the fact that the WRS does not record A8 migrants who are self-employed or not employed and because not all employed migrants register under it. The authors sought to evaluate the reliability of WRS data relative to primary survey work. Research that focuses on A8 migrants in specific areas of Scotland, for example, includes work on Glasgow $^{3}$, Grampian $^{4}$ and Fife ${ }^{5}$. In the Fife survey, 25 per cent of respondents were not registered under the WRS and 13 per cent did not have a NINo. In the Glasgow survey a third of the A8 migrants interviewed were not WRS registered. These results therefore point to the suggestion that WRS data underestimate the scale of East and Central European migration to the country. Other problems with using the WRS as a data source include the issue that migrants are only required to register once they start work, but are not required to de-register when they leave. Thus the WRS only provides data on in-flows of migrants, therefore sometimes only covering their first employment. Many migrants subsequently change job or move location or leave the UK, but these 
later movements are usually not captured by the WRS. Another difficultly is that the WRS uses an unconventional system to classify the sectors in which A8 migrants are in employment, making comparison with other datasets such as the Labour Force Survey difficult. It must therefore be emphasised that the geography of A8 migration that is captured by the WRS is only partial, but it remains very valuable as shown by Bauere et al $^{1}$.

Despite its limitations, the WRS is worthy of careful analysis. Not only does it provide more geographical and sectoral detail than NINo sources, but unlike local surveys (for example, Communities Scotland ${ }^{4}$ ) it permits UK-wide comparisons to be made both geographically and over time. Its greatest strengths are in offering quarterly time series data on new labour migrant arrivals by sector and location and this is how we choose to use the data. For the present study, special tables were commissioned of quarterly WRS data with a breakdown by sector, for UK Government Office Regions as well as for each UK local authority.

\section{A8 migration: spatial, temporal and sectoral trends}

Before turning to focus on immigration during the recession, the article briefly reviews some of the key features of A8 migration to the UK since the 2004 accession. Figure 2 shows WRS registrations May 2004 - June 2010 by economic sector. Many A8 migrants appeared to have worked in the administration, business and management sector (42 per cent of all registrations). The high figure in this grouping is a consequence of the way that registrations are categorised. Most migrants recorded in this group were employed by recruitment agencies (sometimes known as labour providers or gangmasters) but their employment, far from being in 'business', usually involved working under contract for their employers in other parts of the economy such as in agriculture or food processing. As a result of this, data from the administration, business and management sector is not discussed further in this paper.

The next biggest sectors were hospitality and catering (18 per cent), agriculture (10 per cent), manufacturing (7 per cent) and food processing (6 per cent).

The comparison of WRS registrations (May 2004 - June 2010) to the total number of employees working in these sectors (in June 2010) hints at the relative importance of A8 migrant labour to the agricultural sector in particular (Table 1). These calculations are not intended to generate estimates of the specific proportion of A8 migrants in each sector but only give a guide to their relative importance. The potential importance of A8 migrant labour to the agriculture sectors is very striking and certainly accounts in part for the strong spatial concentration of A8 migrants in certain parts of the country. 


\section{Figure $2 \quad$ WRS registrations May 2004 - June 2010 by sector}

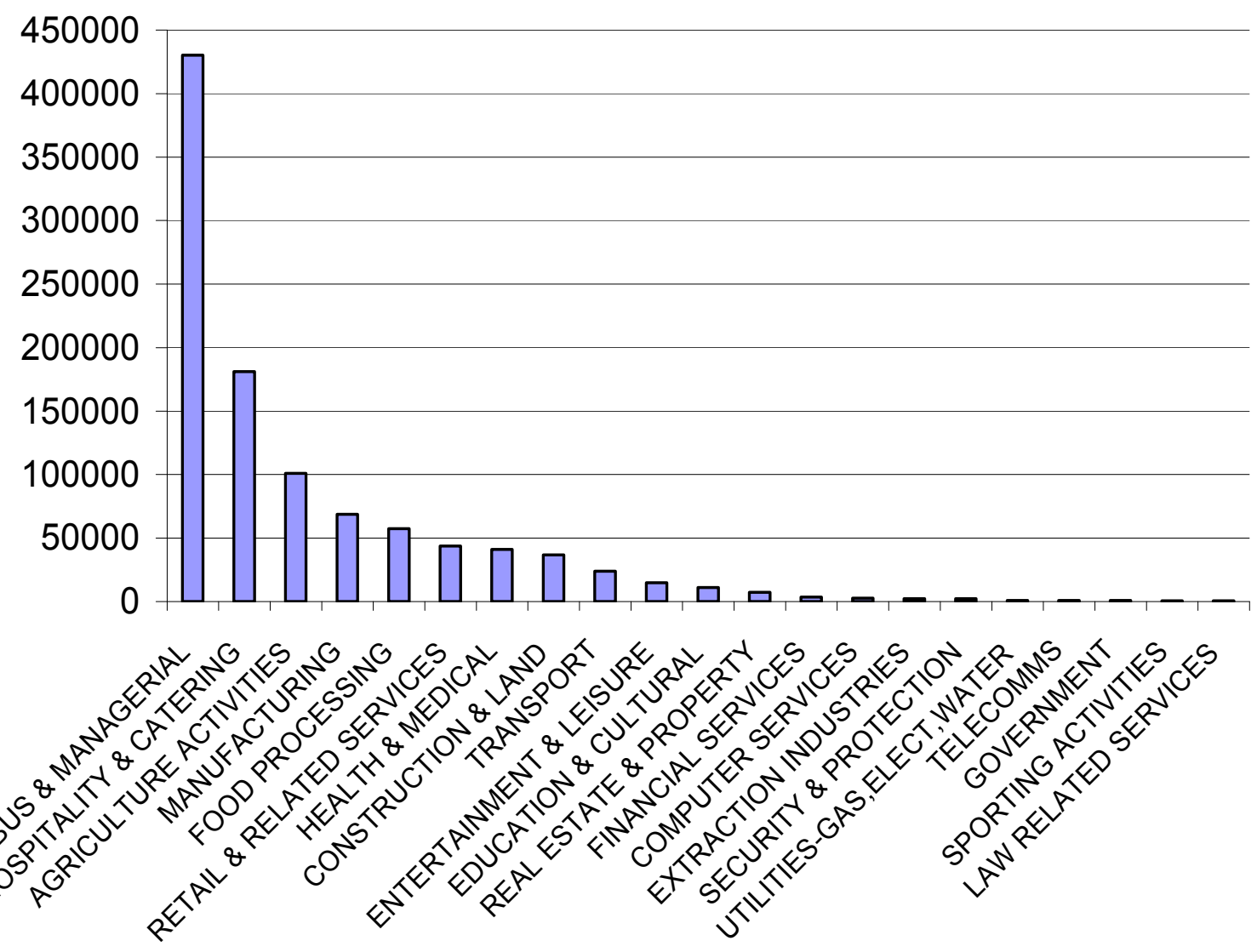

Source: Author's analysis of WRS data

Note: Number of WRS registrations for the sectors with lowest counts: Telecomms (990), Government (790), Sporting Activities (595), Law Related Services (495)

\section{Table $1 \quad$ Estimates of relative importance of A8 migrants by sector}

\begin{tabular}{lrcc}
\hline \multicolumn{1}{c}{ Sector } & $\begin{array}{c}\text { Total WRS registrations } \\
\text { May 2004 - June 2010 }\end{array}$ & $\begin{array}{c}\text { Total employees } \\
\text { June 2010 }\end{array}$ & $\begin{array}{c}\text { A8 migrants May 2004 - } \\
\text { June 2010 as \% of } \\
\text { employee jobs June 2010 }\end{array}$ \\
\hline Hospitality \& catering & 181,120 & $1,739,000$ & 10.4 \\
Agriculture & 101,120 & $251,000^{*}$ & 40.3 \\
Manufacturing & 68,560 & $2,365,000$ & 2.9 \\
Construction & 36,800 & $1,281,000$ & 2.9 \\
Transport & 23,745 & $1,217,000$ & 2.0 \\
Retail & 43,800 & $4,328,000$ & 1.0 \\
Health \& medical & 41,025 & $3,685,000$ & 1.1 \\
Food processing & 57,465 & Not available & Not available \\
All sectors & $1,033,915$ & $27,007,700$ & 3.8 \\
\hline
\end{tabular}

Source: Author's analysis of WRS; ONS ${ }^{6}$

Note: *Includes jobs in forestry and fishing

Figure 3 displays the regional geography of A8 migration. The regions with greatest inflows of WRS registrations over the period May 2004 to June 2010 were London (162,650), the South East $(138,510)$ and the East of England $(127,560)$. 


\section{Figure 3 WRS registrations May 2004 - June 2010 by Government Office Region}

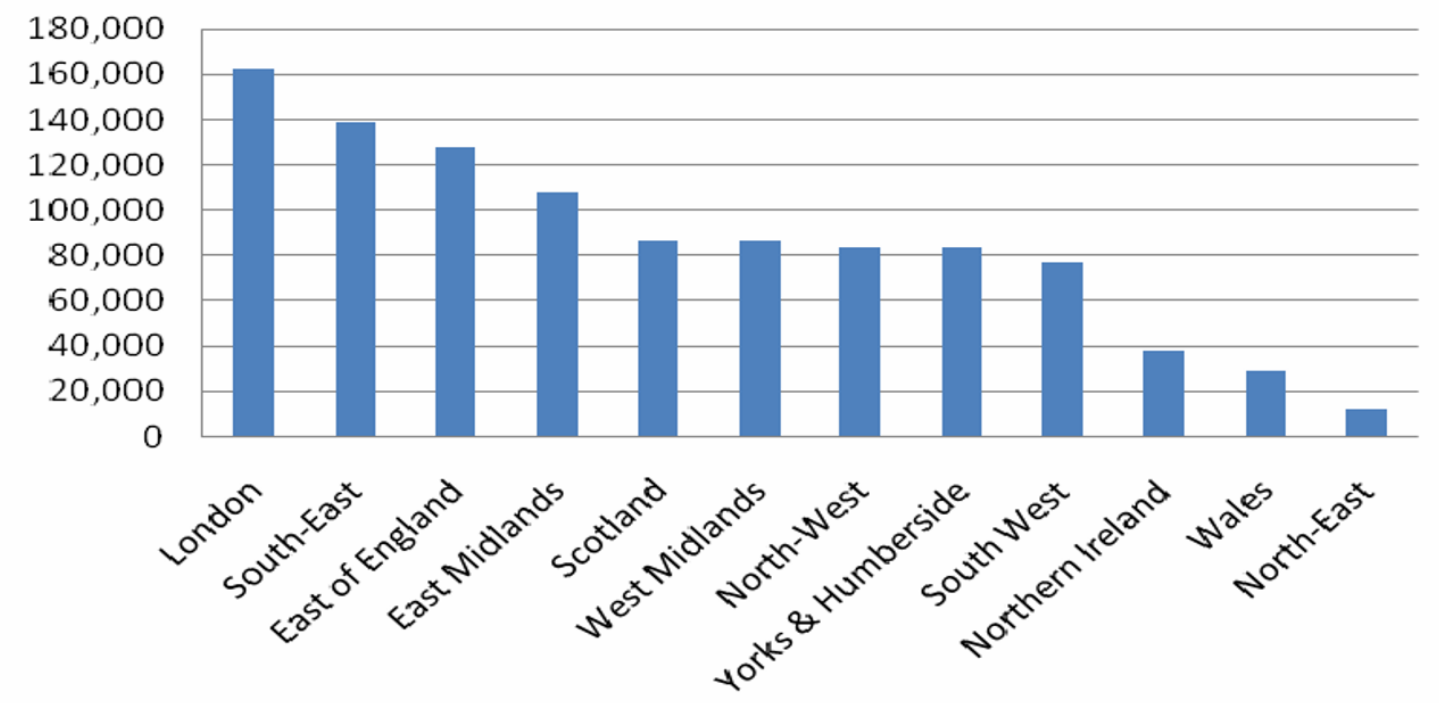

Source: Author's analysis of WRS

\section{Immigration during the recession}

The downward trend in new A8 migrants coming to the UK during the recession, as shown in Figure 1, has been in marked contrast with the rapid rise in numbers during 2004 and 2005, but an interesting feature is that so many migrants continued to enter the UK at a time of rising UK unemployment.

Figure 4 WRS registrations by quarter in the UK April 2006 - June 2010

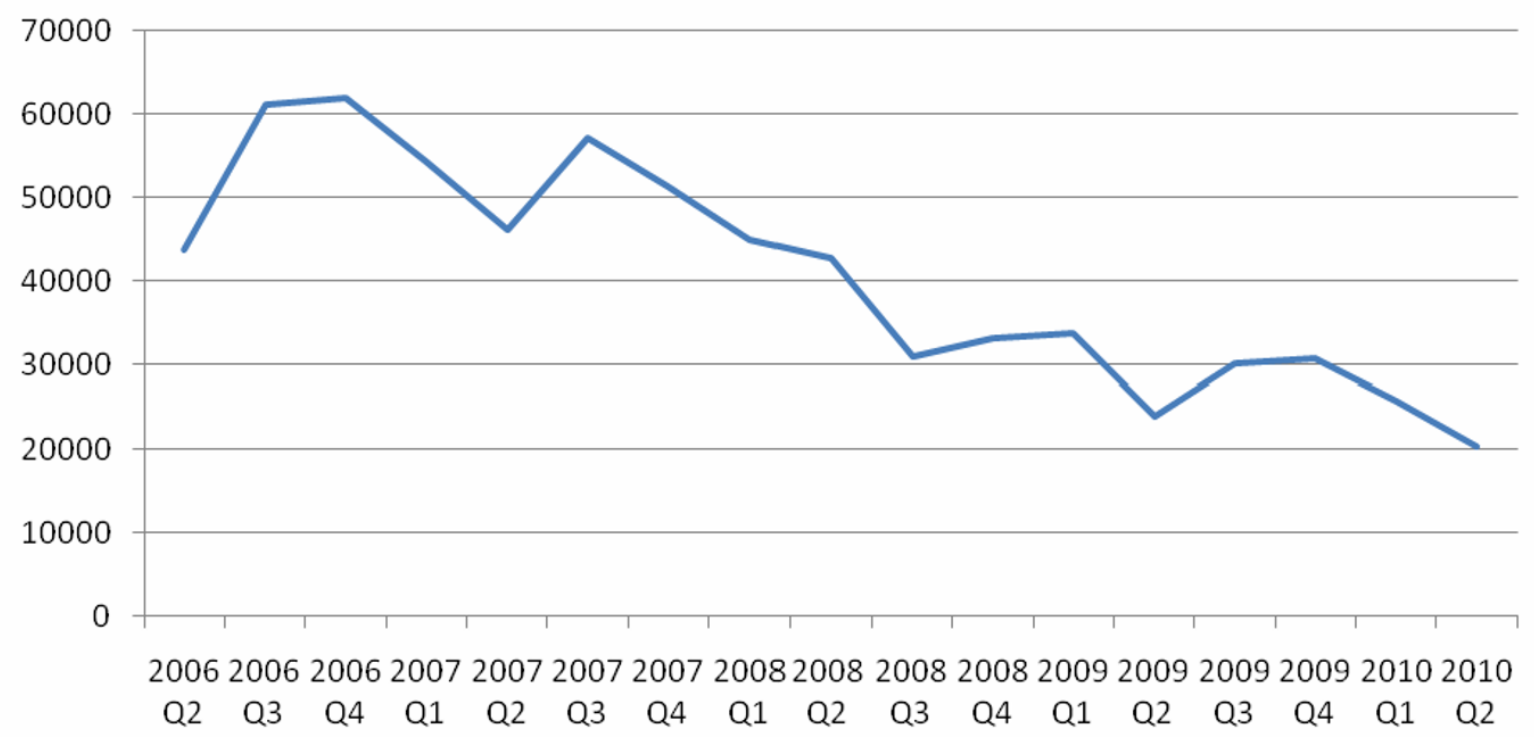

Source: Author's analysis of WRS 
Figure 4 shows quarterly WRS registrations figures between April 2006 and June 2010. As might be expected, the recession seems to have resulted in an overall drop in new WRS registrations. What is striking however is that so many migrants were still arriving between 2008 and 2010 (a total of 316,720 new registrations between January 2008 and June 2010).

Although emigration of some A8 migrants from the UK undoubtedly occurred after the recession started, ONS data reveals that the UK was still gaining more A8 migrants than it was losing throughout this period ${ }^{7}$. In fact Annual Population Survey data (Figure 5) indicates that the number of nationals in the UK from most of the A8 states has actually increased over the period 2007/08 to 2008/09. How can these trends be explained?

\section{Figure 5 Percentage change in nationals in the UK between July 2007 - June 2008 and July 2008 - 2009*, A8 states}

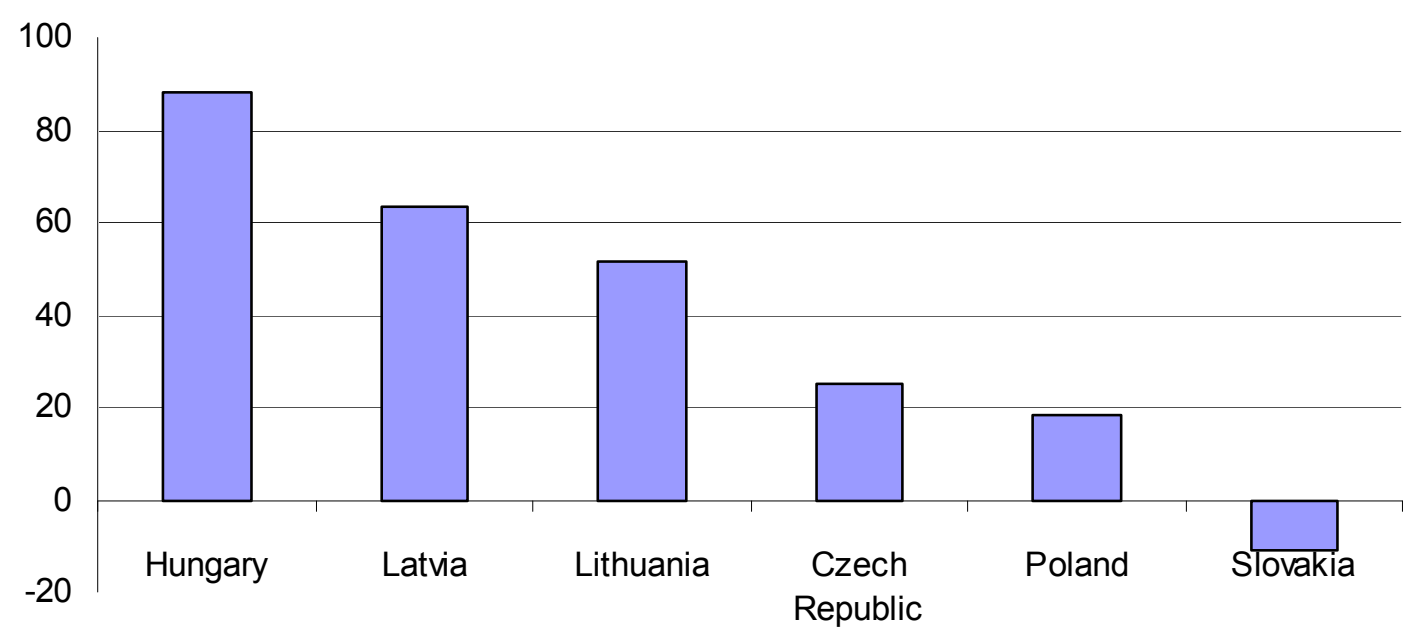

Source: Author's analysis of Annual Population Survey data, ONS ${ }^{8}$

Note: *Estonia and Slovenia are not included as their low sample sizes in the Annual Population Survey make estimates of their population size unreliable.

One reason for new WRS registrations is that around half of A8 migrants do not remain in the UK on a permanent basis ${ }^{9}$, being employed only on a seasonal basis, and re-registering every year on re-entry. Dustmann et al $^{10}$ show that many young well educated East Europeans accept seasonal jobs earning lower wages than the average for the UK workforce, before returning home. The continuation of the circulating pattern is not surprising given seasonal cycles in parts of the UK economy, most notably in hospitality, catering and agriculture.

A second significant feature is the so-called 'complementary' nature of much of the work undertaken by $\mathrm{A} 8$ migrants ${ }^{11}$. A growing body of evidence indicates that many migrants accept jobs in the UK that local employers find hard to fill with domestic labour ${ }^{12,13}$. It is not only an issue of migrants accepting the dirty, difficult and dangerous jobs that the UK labour force shuns, but also a matter of the very positive work ethic amongst A8 workers and their willingness to engage in work routines that have permitted the intensification of production, for example, in parts of the agricultural sector. Although agriculture, like other sectors of the economy, has been affected by the recession, there remains a story of demand for migrant labour to allow the continuation of 
these labour intensive production systems ${ }^{12}$. In these sectors migrant labour is therefore complementary to the UK labour force, and thus during the recession there has been a continued flow of A8 workers, as shown in Figure 5. The spatially concentrated nature of these production systems has in turn meant geographically uneven patterns of migrant labour demand during the recession.

The second quarter of 2008 is widely seen as the last economic quarter of 'normal' economic activity before the onset of the recession. ONS records this as the quarter that saw an end to 16 years of unbroken GDP growth. Thereafter the UK unemployment claimant count and redundancy levels rose and vacancy levels fell ${ }^{14}$. By quarter two of 2009 the economy was at the lowest point of the recession and new WRS registrations were in a trough. Thereafter the decline in the fortunes of the economy began to slow and WRS registrations picked up slightly ${ }^{14}$. In order to analyse the overall effects of the recession on migration in more detail, new migrant registrations in the second quarter of 2008 were compared with those of the second quarter of 2009.

Table 2 shows the change in WRS registrations in the UK between 2008 (quarter two) and 2009 (quarter two) for the top ten sectors in which A8 migrants were employed. All of these sectors recorded a drop in new WRS registrations, but the level of contraction was uneven. When the overall rate of decline in new registrations (all sectors) of 43.8 per cent was compared with the decline in each individual sector, it was found that the recession resulted in a disproportionate reduction in new A8 migrants in the real estate and construction sectors compared to the overall trend. When the absolute observed and expected reductions were compared using Chi-square tests the reduction in the transport and manufacturing sectors were also shown to be statistically significant. Inversely, there was a much lower than expected reduction in the inflow of migrants to the agricultural and food processing sectors.

\section{Table 2 Decline in new WRS registrations by sector 2008 Q2 - 2009 Q2, UK}

\begin{tabular}{ll}
\hline WRS Sector & $\begin{array}{l}\text { \% } \\
\text { change }\end{array}$ \\
\hline Real estate \& property* & -77.78 \\
Construction \& land* $^{*}$ & -75.48 \\
Transport* $^{*}$ & -69.83 \\
Manufacturing* $^{*}$ & -65.97 \\
Retail & -49.47 \\
Administration, business \& managerial & -41.99 \\
Hospitality \& catering & -40.75 \\
Health \& medical & -35.71 \\
Food processing $^{*}$ & -34.41 \\
Agricultural activities* & -28.52 \\
Average for all sectors & -43.85 \\
\hline
\end{tabular}

Source: Author's analysis of WRS

Note: * Chi-Square significance 0.001

Table 3 shows how the number of WRS registrations has changed in the top five sectors in which A8 migrants were employed. It compares these trends with employment change for all employees 
in these sectors. Not surprisingly, both A8 registrations and employment levels generally have decreased over the course of the recession; however these changes have been sectorally uneven. Migrants' employment in construction appears to have been particularly sensitive to the job losses that have occurred in that sector. Agriculture emerges as different from other sectors in terms of trends in employment patterns. Less than one percent of all jobs in the UK are in agriculture, yet up to 40 per cent of all employees in this sector in 2010 might have been A8 workers (Table 1). A8 migrants certainly make up a much larger proportion of the workforce in agriculture than they do in any other sector in the UK, and yet as the figures in Table 3 show demand for A8 migrant labour, although reducing, has been much less affected by the recession than in other sectors.

\section{Table 3 Change in WRS registrations and employee jobs by sector Q2 $2008-$ Q2 2009}

\begin{tabular}{lccc}
\hline Sector & $\begin{array}{c}\text { Change in WRS } \\
\text { registrations 2008 Q2 - } \\
\text { 2009 Q2 }\end{array}$ & Sector (SIC equivalent) & $\begin{array}{c}\text { Change in total number } \\
\text { of employees 2008 Q2 - } \\
\text { 2009 Q2 }\end{array}$ \\
\hline Agriculture & $-28.5 \%$ & Agriculture, forestry \& fishing & $-8.7 \%$ \\
Construction \& land & $-75.5 \%$ & Construction & $+0.2 \%$ \\
Hospitality & $-40.8 \%$ & Hotels \& catering & $-2.9 \%$ \\
Manufacturing & $-66.0 \%$ & Manufacturing & $-7.6 \%$ \\
All sectors & $-43.9 \%$ & All sectors & $-2.9 \%$ \\
\hline
\end{tabular}

Source: Author's analysis of WRS; ONS ${ }^{6}$

Note: *WRS data classification

The sectoral pattern outlined above is visible when one considers the geography of how A8 migration trends have varied over the course of the economic downturn. Table 4 shows the areas in the UK with the most A8 registrations May 2004 - December 2006 as a proportion of total population size in 2006 (as calculated by Bauere et al $^{1}$ ). Added to these estimates is a measure of how new WRS registrations have changed over the recession (2008 Q2 - 2009 Q2). Prior to the recession (middle column) the top concentrations of A8 migrants were a mixture of urban and rural local authorities. With the recession, three of the four rural areas (South Holland, Fenland and Herefordshire) have seen a below UK average drop in WRS registrations. On the other hand half of the six urban areas (City of London, Northampton and Peterborough) experienced higher than UK average declines in WRS registrations with the recession. These figures broadly support the view that although recession has brought about a reduction in the number of new A8 migrants coming into the UK as a whole, the effect has been geographically uneven with much lower reductions in migrant labour participation in rural agricultural labour markets than in other sectors of the UK economy, and especially relative to urban areas where the decline has been much more rapid.

Primary data collected by the authors and involving 61 interviews conducted with the users (employers) and providers (recruitment agencies) of A8 migrant labour in the hospitality and food production and processing sectors across the UK between January 2010 and October 2010 substantiates the findings discussed above. In almost all of the interviews, A8 migrant labour was viewed in positive terms, with these workers being described as having a strong work-ethic and often being compared favourably with domestic labour. However, as was the case with the WRS 
data analysis, the research identified significant spatial, sectoral and temporal variations in how A8 labour was perceived and used ${ }^{16}$.

\section{Table 4 Top ten local authorities: A8 citizens registered per thousand of total population, Q2 $2004-$ Q4 2006 and change in WRS registrations Q2 2008 - Q2 2009}

\begin{tabular}{lccc}
\hline Local Authority & $\begin{array}{c}\text { Mainly rural or } \\
\text { urban* }\end{array}$ & $\begin{array}{c}\text { WRS registrations } \\
\text { (Q2 2004 - Q4 2006) as } \\
\text { \% of total population }\end{array}$ & $\begin{array}{c}\text { Change in WRS registrations } \\
\text { Q2 2008 - Q2 2009 }\end{array}$ \\
\hline City of London & Urban & 294 & $-47 \%$ \\
Boston & Urban & 97 & $-20 \%$ \\
Westminster & Urban & 62 & $-33 \%$ \\
Northampton & Urban & 53 & $-52 \%$ \\
South Holland & Rural & 50 & $0 \%$ \\
Peterborough & Urban & 45 & $-47 \%$ \\
Fenland & Rural & 40 & $+4 \%$ \\
East Cambridgeshire & Rural & 39 & $-74 \%$ \\
Herefordshire & Rural & 38 & $-29 \%$ \\
Dungannon** & N/A & 37 & $-65 \%$ \\
UK & N/A & 8 & $-44 \%$ \\
\hline
\end{tabular}

Source: Adapted from Bauere et al ${ }^{1}$; author's analysis of WRS

Notes: *Based on '\% rural' LA classification, ONS ${ }^{15}$

${ }^{* *}$ Classification only includes England and Wales

The perception of some A8 migrant labour as different from UK employees was found most often amongst employers in rural areas involved in the food production and processing sectors. In these cases, A8 migrants were often regarded as distinct from domestic labour in terms of their attributes and work ethic, with employers viewing this source of labour as essential to their functioning:

Because it is minimum wage work on a factory floor no Scottish people want to do it and the Eastern Europeans are the only ones that will. The locals are not really interested unfortunately because they'd rather be on benefits but our European workers are a great bunch, really hard working and diligent and if we didn't have them we'd be in real trouble so it gets on my nerves when people complain about migrant workers because this country could not do without them.

(June, operations director, food processing company, rural Scotland)

The perception of A8 migrant labour as a positive but not essential supply of labour in urban areas and in the hospitality sector, but as a core workforce in rural areas and in the food production and processing sectors, has had implications for the demand for migrant labour in recession. Like the WRS data, the interviews suggest that the impact of the recession on demand for migrant labour has differed between urban and rural areas and between agribusiness and sectors such as hospitality. In urban areas and in the hospitality sector the demand for A8 migrant labour has decreased substantially as the recession means fewer jobs generally and increased competition for them from domestic labour: 
Before the recession in the hospitality sector there were probably more jobs than we had people for so that created the demand for Eastern Europeans to fill those positions. But now those jobs aren't there and we have got quite a high number of unemployed people in the UK so the demand for bringing in the extra people to fill those jobs is just not there.

(Gerald, director, labour provider firm, urban Scotland)

However in the agribusiness sector and in rural areas the demand for migrant labour has been more resilient as employers complain of struggling to source domestic labour regardless of prevailing economic circumstances:

Most of my workers are Eastern Europeans and that is because the locals don't want to seem to work here, the pay isn't great and it's pretty boring work... just before the recession I was worried about getting workers but now l've got lots of people coming in or phoning up and looking for a job but again they're all Eastern Europeans - you never get the locals doing that.

(Frank, production manager, food processing plant, rural Scotland)

\section{Discussion and conclusions}

Despite its limitations, the WRS remains the most detailed information source on the temporal, spatial and sectoral trends in A8 labour migration. With the end of the A8 transition phase, the WRS will no longer be maintained. This analysis has therefore sought to make best use of this time-specific data source to investigate the prominence of A8 migration in contemporary UK immigration flows, the geography and employment patterns of A8 migration and the impact of the recession on these trends. It has been shown that since the onset of the recession, the volume of new A8 migrants entering the UK has declined to a greater extent than it has for other migrant groups (Figure 1). Despite this the overall number of migrants from most A8 countries continued to grow even during the recession (Figure 4).

Analysis of the WRS shows that the pattern of recent A8 immigration has been spatially and sectorally uneven. The biggest reductions in migrant numbers coming to the UK have been in the construction and real estate sectors and the smallest drops have been in the agricultural and food processing sectors (Table 3). Comparisons of the decline in new WRS registrations against employee job losses over the recession generally suggest that A8 migrant labour has been particularly sensitive to the recession (relative to job losses amongst UK domestic labour) in the construction and hospitality sectors. The number entering to work in agriculture, although less than in the past, remain significant.

Analytically, these trends suggest that A8 migration may be fulfilling two distinct functions in the UK labour market. On the one hand, many WRS registrations have been in the construction and manufacturing sectors. The recession has seen significant reductions in the number of new A8 migrants entering these sectors. This trend supports the concept of migrants acting as a malleable supply of additional labour, which has meant that demand for it has been highly sensitive to business cycles and to the recession. By contrast, in agriculture the overall drop in new WRS registrations and the decline relative to domestic job losses has been much less than in other sectors of the economy. This may reflect the 'core' position of A8 migrants in the agribusiness 
industry. In agriculture, demand for migrant labour has been less sensitive to changes in the business cycle. Employers in this sector have found it difficult to source domestic labour, regardless of prevailing economic conditions.

These conclusions, based on UK-wide WRS data, reflect earlier academic analysis of similar trends in Scotland ${ }^{16}$. Both pieces of research seek to contribute to deepening our understanding of the nature of A8 migration trends to the UK and the relationship between international labour market migration and recessionary economic circumstances.

\section{References}

1 Bauere, V. Densham, P. Millar, J. and Salt, J. (2007). 'Migrants from central and eastern Europe: Local geographies'. Population Trends, vol 129, pp. 7-19.

2 Department for Work and Pensions (2010). 'NINo Registrations to Adult Overseas Nationals entering the UK'. DWP Tabulation Tool. Available at:

http://83.244.183.180/mgw/live/mw/tabtool mw.html

Accessed 17 March 2010.

3 Glasgow City Council. (2007) ‘A8 Nationals in Glasgow'. Blake Stevenson’s Report. Available at:

www.asylumscotland.org.uk/assets/downloads/research/A8NationalsinGlasgowMay2007.pdf Accessed 16 March 2010

4 Communities Scotland. (2007). 'A study of migrant workers in Grampian'. Available at: www.scotland.gov.uk/Resource/Doc/1125/0086220.pdf Accessed 16 March 2010.

5 Fife Partnership. (2007). Migrant Workers in Fife - Survey 2007. Fife Research CoOrdination Group. Available at:

www.asylumscotland.org.uk/assets/downloads/research/KnowFifeMigrant\%20Workers.pdf Accessed 16 March 2010.

6 Office for National Statistics. (2011a). Employee Jobs by Industry. Available at: www.ons.gov.uk Accessed 26 April 2011.

7 Office for National Statistics. (2011b). Migration Statistics Quarterly Report Number 8, February 2011. Available at: www.ons.gov.uk/ons/rel/migration1/migration-statisticsquarterly-report/february-2011/migration-statistics-quarterly-report.pdf Accessed 11 May 2011.

8 Office for National Statistics (2010). 'Population by country of birth and nationality from the Annual Population Survey'. Available at: www.ons.gov.uk/ons/search/index.html?contenttype=Publication \&pubdateRangeType=allDates\&newquery $=\% 27$ Annual+Population+Survey \%27\&pageSize=50\&applyFilters=true Accessed 11 May 2011. 
9 Blanchflower, D. Saleheen, J. and Shadforth, C. (2007). 'The Impact of the Recent Migration from Eastern Europe on the UK Economy'. Institute for the Study of Labour. Discussion paper Number 2615. Available at: ftp://repec.iza.org/RePEc/Discussionpaper/dp2615.pdf Accessed 17 March 2010.

10 Dustmann, C. Frattini, T. and Halls, C. (2010). 'Assessing the Fiscal Costs and Benefits of A8 Migration to the UK'. Fiscal Studies Vol 31 No 1. pp 1-41.

11 Tamas, K. and Munz, R. (2006). Labour Markets Unbound? EU Enlargement, Transitional Measures, and Labour Market Effects. Institute for Futures Studies. Stockholm.

12 Rogaly, B. (2008). 'Intensification of Workplace Regimes in British Horticulture: The Role of Migrant Workers'. Population, Space and Place Vol 14. pp 497-510. Spencer.

13 Cangiano, A. Shutes, I. Spencer, S. and Leeson, G. (2008). Migrant workers in Ageing Societies. Compas. Oxford

14 Office for National Statistics. (2009b). 'The Impact of the recession on the labour market'. Available at: www.ons.gov.uk/ons/rel/Imac/impact-of-the-recession-on-the-labourmarket/impact-of-the-recession-on-the-labour-market/impact-of-the-recession-on-the-labourmarket---impact-of-the-recession-on-the-labour-market.pdf Accessed 26 March 2010.

15 Office for National Statistics. (2009a). 'LA classification'. Available at: www.ons.gov.uk/ons/guide-method/geography/products/area-classifications/rural-urbandefinition-and-la/rural-urban-local-authority--la--classification--england-/index.html Accessed 13 May 2011.

16 Findlay, A. Geddes, A. and McCollum, D. (2010). 'International Migration and Recession'. Scottish Geographical Journal Vol 126 No 4. pp 299-320. 